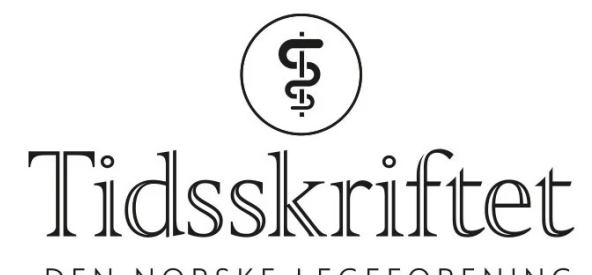

DEN NORSKE LEGEFORENING

\title{
Sunn mat kan kompensere for genetisk risiko
}

FRA ANDRE TIDSSKRIFTER

KETIL SLAGSTAD

Tidsskriftet

De som genetisk sett har lett for å bli overvektige, har særlig nytte av et sunt kosthold for å gå ned i vekt. Det viser en ny studie.

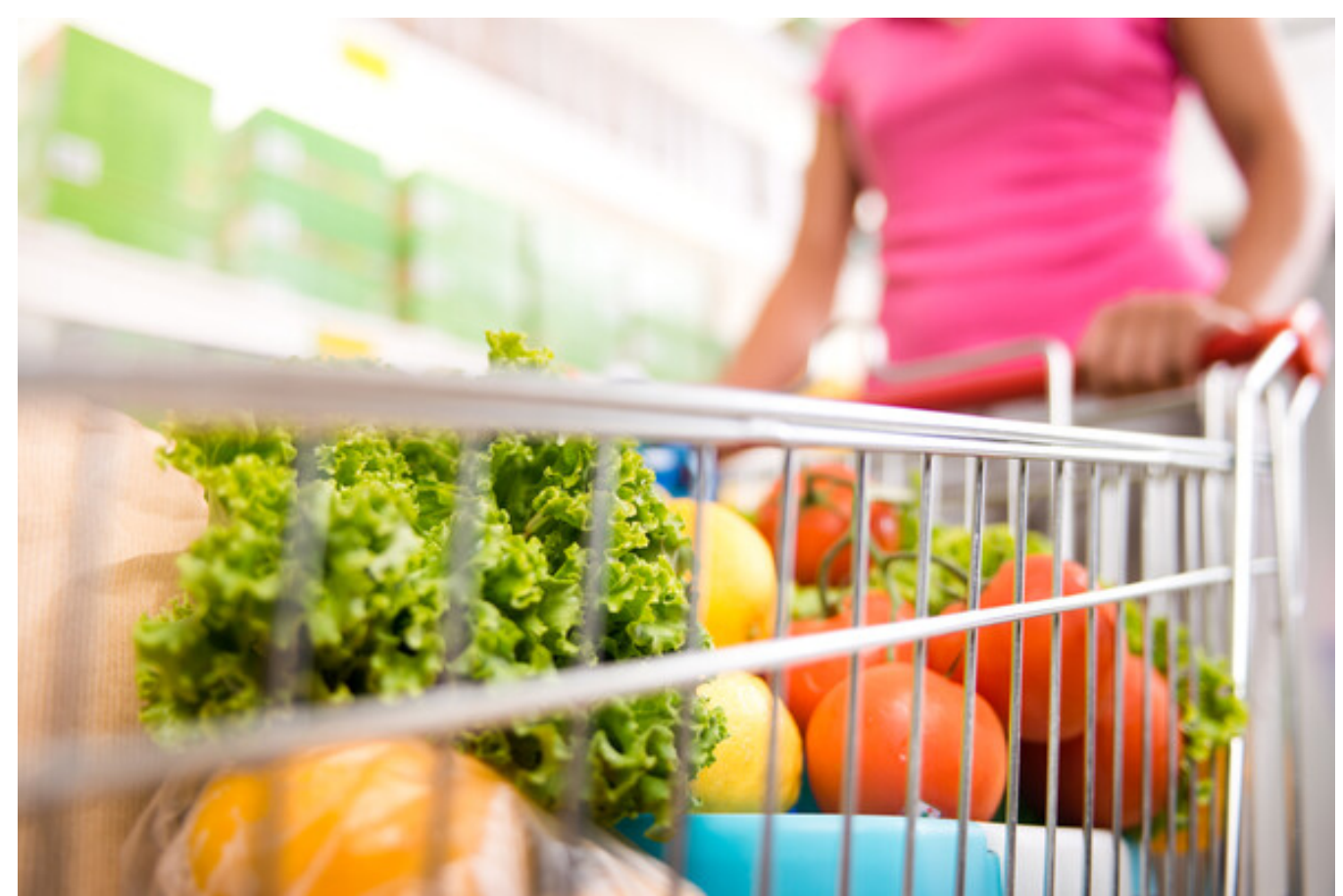

Fem om dagen er bra. Illustrasjonsfoto: cyano66/iStock

Overvekt skyldes et samspill mellom gener og miljø. I en ny studie som nylig er publisert i tidsskriftet BMJ, ble 14 ooo personer fulgt over 20 år (11). Genetisk predisposisjon for overvekt ble fastslått på grunnlag av 77 enkeltnukleotidpolymorfismer.

Kostholdsregistreringer ble omregnet til en skår som gikk fra sunt til usunt i henhold til 
anerkjente skåringsinstrumenter. Analysene viste at personer med genetisk $ø$ kt risiko for overvekt hadde særlig nytte av et sunt kosthold og oppnådde størst reduksjon i kroppsmasseindeks.

- Denne studien viser for første gang betydningen av et sunt kosthold for vektendring over tid hos dem som er genetisk disponert for overvekt, sier Stine Marie Ulven, som er professor i ernæring ved Universitetet i Oslo.

- Den er basert på to store kohorter, men den omfatter bare amerikanske helsearbeidere av europeisk opprinnelse, noe som begrenser generaliserbarheten. Funnene må derfor bekreftes i studier i andre demografiske og etniske grupper, sier Ulven. Hun legger til at studien er relevant for Norge, ettersom matvarene som ble regnet som sunne, er de samme som norske myndigheter anbefaler oss å spise.

\section{LITTERATUR}

1. Wang T, Heianza Y, Sun D et al. Improving adherence to healthy dietary patterns, genetic risk, and long term weight gain: gene-diet interaction analysis in two prospective cohort studies. BMJ 2018; 36o: j5644. [PubMed][CrossRef]

Publisert: 19. mars 2018. Tidsskr Nor Legeforen. DOI: 10.4045/tidsskr.18.0o89

(C) Tidsskrift for Den norske legeforening 2023. Lastet ned fra tidsskriftet.no 26. april 2023. 